Mitteilungen der Österreichischen Geographischen Gesellschaft, 162. Jg., S. 123-154

(Annals of the Austrian Geographical Society, Vol. 162, pp. 123-154)

Wien (Vienna) 2020, https://doi.org/10.1553/moegg162s123

\title{
Transferring the Territorial Cohesion Ideal of Integrated Polycentric Development in the Light of Peripheralisation - Insights From Romania
}

\author{
Alexandru BRAD, Braunschweig* \\ Initial submission / erste Einreichung: 05/2020; revised submission / revidierte Fassung: 09/2020; \\ final acceptance / endgültige Annahme: 11/2020 \\ with 3 figures and 4 tables in the text
}

\section{CONTENTS}

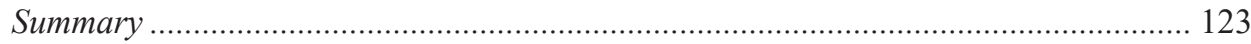

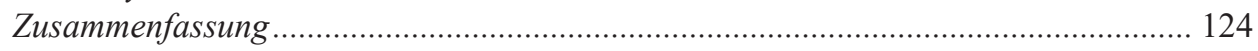

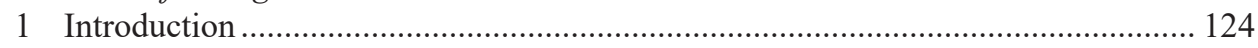

2 The "integrated polycentric development" ideal: a transferable contradiction? ...... 126

3 An actor-centered conceptual framework for a bottom-up understanding of

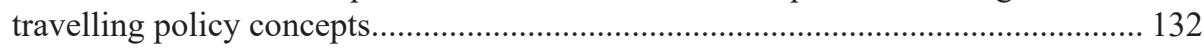

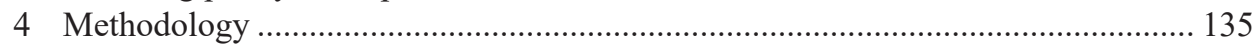

5 Decentered perspectives on Romania's growth pole-driven polycentric

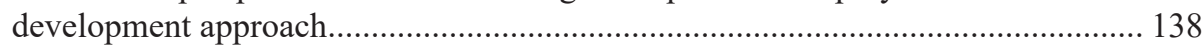

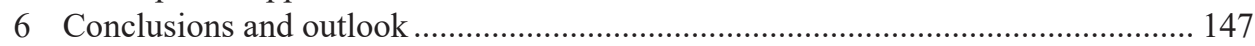

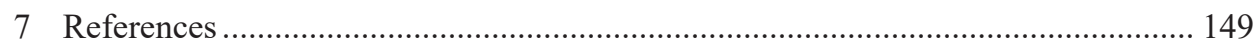

\section{Summary}

In this article I explore the transfer of the territorial cohesion ideal of integrated polycentric development from the European Union's (EU) institutional core towards the peripheral places of a Romanian region. The literature review explores the emergence of polycentric development as an attempt of reconciling divergent EU-wide spatial visions of growth and cohesion. I also explore the institutional particularities that shape the transfer of territorial cohesion in South-Eastern EU Member States. Drawing on Mark BEVIR's and Rod RHODES' "Decentered Governance Approach", I design a conceptual framework to analyse this transfer through an actor-centered bottom-up perspective.

\footnotetext{
* Alexandru Brad, M.A., Research associate, Johann Heinrich von Thünen Institute, Federal Research Institute for Rural Areas, Forestry and Fisheries, Bundesallee 50, D-38116 Braunschweig, Germany. - Email: alexandru. brad@thuenen.de.
} 
My empirical material draws on qualitative research (policy document analysis and semi-structured expert interviews) conducted at the local, regional, and national levels. My analysis highlights the decision-making practices that underpin the making and implementing of urban and regional development policies. It examines the key substantive and governance narratives that underlie integrated polycentric development. I conclude the paper by highlighting the dominance of the concentrated growth development paradigm and make the case for territorial development concepts that are more sensitive to issues of peripheralisation.

Keywords: Territorial cohesion, integrated territorial development, polycentricity, EU Cohesion policy, policy transfer, Romania

\section{Zusammenfassung}

\section{Die ÜBERTRAGUNG DES TERRITORIALEN KOHÄSIONS-IDEALS VON INTEGRIERTER POLYZENTRISCHER ENTWICKLUNG ANGESICHTS VON PERIPHERISIERUNGSPROZESSEN - ERKENTNISSE AUS RUMÄNIEN}

In diesem Beitrag untersuche ich die Übertragung des territorialen Kohäsions-Ideals von integrierter polyzentrischer Entwicklung vom institutionellen Zentrum der Europäischen Union auf die peripheren Orte einer rumänischen Region. Dabei greife ich auf Literaturquellen, die den Fokus auf den Einfluss setzen, den die zentrale Spannung der Vereinbarkeit von Wachstum und Kohäsion auf die Entwicklung des Begriffs als flexibles Konzept hatte. Analysiert werden auch die institutionellen Besonderheiten, die den Transfer des Konzepts prägen. Auf der Grundlage des dezentralen Governance-Ansatzes von Mark BEVIR und Rod RHODES entwerfe ich einen konzeptionellen Ansatz, der die Analyse dieses Transfers durch eine akteurszentrierte Bottom-up-Perspektive ermöglicht.

Meine Analyse beleuchtet die Entscheidungspraktiken und die Governance-Narrative, die der Gestaltung und Umsetzung von territorial integrierten Entwicklungspolitiken zugrunde liegen. Zum Schluss hebe ich die Dominanz des konzentrierten wachstumsorientierten Entwicklungsparadigmas hervor und plädiere für integrierte territoriale Entwicklungskonzepte, die die von Peripherisierungsprozessen verursachten Probleme stärker berücksichtigen.

Schlagwörter: Räumliche Kohäsion, integrierte räumliche Entwicklung, Polyzentralität, Kohäsionspolitik, Politiktransfer, Rumänien

\section{Introduction}

In this article I explore the transfer of the territorial cohesion ideal of integrated polycentric development from the European Union's (EU) institutional core towards the peripheral places of a Romanian region.

Territorial cohesion, together with economic and social cohesion, is an inherent dimension of the European Union's Cohesion Policy. The concept supports "reducing disparities between the levels of development of the various regions and the backwardness of the 
least favoured regions" (Consolidated Version of the Treaty on the functioning of the European Union 2012, art. 174).

Given this inextricable link to the Cohesion Policy, research on the transfer of territorial cohesion ideals in South-Eastern European (SEE) regions has mostly focused on the Policy's effect upon Member States' sectoral and regional policies (CsuKA 2018; BLAŽEK and MACEŠKOV́́ 2018), on the polarising spatial trends it underpins (SMĘTKOWSKi 2013; MEDVEBÁLINT 2018), or on its contribution to consolidating institutional capacities for regional economic development (DĄBROWSKI 2014). Moreover, a considerable amount of thought has been put into defining "territorial cohesion" at the EU level (e.g., European Spatial Planning Observation Network 2013; Commission of the European Communities 2008).

Recent spatial development trends in SEE motivated me to engage with this topic. On the one hand, the trend of economic growth in this part of the continent has for the past decade generally been positive (European Commission 2017). On the other hand, disparities between and within regions have stubbornly persisted, not only in economic performance (Chilla and Neufeld 2015, pp. 210-212) but also in life quality (HANell 2018, p. 196). Briefly put, the economic perspectives for places outside urban agglomerations are unconvincing, at best. Low-income traps, long periods of economic decay, persisting trends of socio-spatial marginalisation and migration, or a loss of political relevance are but a few of the challenges faced by these regions (LUUKKONEN 2010; HerRSCHEL 2011; RODRÍGUEZ-Pose 2017).

The persistence of such trends in the EU is even more puzzling, since concepts like territorial cohesion have been purposefully designed to counteract these tendencies. Could it be that such "grand constructs" lose their intended meaning when travelling from institutional cores to the contexts for which they are designed? Scholars have recently called for research on the localised interpretations and reconstruction of territorial cohesion ideals (GUALINI 2008; ERNSTE 2012; ABRAHAMS 2014). I see this as an invitation to explore the transfer of territorial cohesion ideals from a bottom-up perspective.

I ask the following research question: Under which institutional conditions is the territorial cohesion ideal of integrated polycentric development re-interpreted in the national contexts of SEE Member States? Appended to this is the following sub-question: To what extent could key tensions inherent to the notion of integrated territorial cohesion be resolved in its bottom-up interpretation?

The second part of the paper focuses on the key tensions inherent in the territorial cohesion ideal of integrated polycentric development. I also discuss the transferability and applicability of integrated polycentric development in SEE regions. Then, the third section sketches a bottom-up framework for researching policy transfer. Using BEVIR's and RHODES's (2010) decentered approach, I make a case for focusing on the "in-situ" conditions in which policy terms and wider goals are re-interpreted.

After an outline of the methodology in the fourth section, the fifth part details the use of polycentric development in Romania. I draw on empirical fieldwork in national and regional policy communities to show the agencies involved in operationalising the concept and to examine the consequent policy process in a region dominated by one metropolis. The conclusions summarise the paper's main points and sets forward a set of principles for a more context-sensitive (re-)interpretation of territorial cohesion. 


\section{The "integrated polycentric development" ideal: a transferable contradiction?}

One of the key conundrums of the territorial cohesion construct as a whole, and its constituting ideals in particular, is their lack of an actionable, policy-bound definition (Abrahams 2014; Medeiros 2016; Demeterova et al. 2020b). Right from the outset, this absence creates a two-sided obstacle in setting the term's normative boundaries. On the one hand, the term "territorial cohesion" invites abstractions that are too sophisticated and unrealistic - see for instance RADEJ and GoloBIČ's (2018, p. 42) critique of European Spatial Planning Observation Network (2007, pp. 75-76). While these abstractions do indeed bestow the term with a sophisticated internal structure, they are nonetheless based on contextualised assumptions (that is, grounded understandings in contrast to high-level abstractions) about development trajectories. The impracticability of transferring grounded abstractions lies in the difficulty of decontextualising the specific geographic and socioeconomic conditions that have informed their design (Maloutas 2018, p. 251). The resulting concepts and the theories which underpin such concepts are not sufficiently general but tend to be treated as if they were (ibid.).

This is where the second challenge enters: the over-politicisation of "territorial cohesion" (MULLER 2013, p. 244). Simply put, political definitions and ideas about their implementation diverge between the actors who operationalise the notion of "territorial cohesion". At the European level, the key contribution of "territorial cohesion" appears to have been the crystallisation of the growth and concentration-driven economic competitiveness narrative (OthengRAFEN and CoRnett 2013, p. 21; LUUKKONEN 2010, p. 445; Avdikos and Chardas 2015, p. 19). While this European vision is non-binding for its Member States, it is hardly indicative of a primordial concern for cohesion, particularly with regard to institutional relations. In this sense, an EU-wide perception of political peripherality has been emerging steadily, driven predominantly by an insufficient transfer of decision-making power at the regional and local levels (LUUKKONEN 2010, p. 461). The nature of the core-periphery relations in policy transfer is hence not only one of uneven knowledge dissemination flows (MALOUTAs 2018, p. 251), but also, as I will go on to argue, one of solidifying political dependencies.

In this section I explore "integrated polycentric development" as a transferrable construct in contexts of rising socio-spatial disparities. In the first subsection I highlight how the term's normative dimension has been designed to flexibly tackle its inherent fundamental tension between concentration and redistribution. In the second subsection I will briefly discuss the institutional particularities of the SEE contexts.

\subsection{The inherent tension within the integrated polycentric development ideal}

As an integral part of the Cohesion Policy, the notion of territorial cohesion has been underpinned by an unreconciled duality between two opposing policy ideals (according to BEGG 2010, p. 93). To put it briefly: on the one hand, territorial cohesion pursues balance and redistribution, while seeking, on the other hand, to favour concentration and compet- 
itiveness. There are three prominent policy situations that have shaped the meanings of polycentric development in light of this tension.

A first policy situation was the assigning of the "balanced competitiveness" aim to polycentric development in the European Spatial Development Perspective - ESDP (Commission of the European Communities 1999; for a comprehensive overview of the ESDP process see FALUDI and WATERHOUT 2002). Here, the "competitiveness" side is the materialisation of a claim made by Member States whose territories formed the bulk of the Union's spatial core (see Western Europe's tightly interlinked polycentric structure in Figure 1). Representatives of these countries supported the position that the well-being of the EU depends on the well-being of its core (WATERHout 2008, p. 65-66). It was therefore argued that the ESDP ought to be conceptually oriented (and consequently EU Structural Investment (ESI) Funds) towards addressing competitiveness barriers within urban areas (e.g., by promoting infrastructure renewal or addressing the urban decay resulting from deindustrialisation). On the other hand, the "balance" side was rooted in the concerns for cohesion that were voiced by the southern Member States. This position was underpinned by the claim that the integration within the Single Market generated disparities between its participating Members. Hence, the case was made for a redistributive take on the ideal of polycentric development, focusing on urban-rural relations and decentralisation, amongst others. The rather vague resulting notion of "balanced competitiveness" was the outcome of a political compromise between the two strong normative positions (WATERHOUT 2008, p. 74). Observers of the process claim that this basic ambiguity within the notion of polycentricity was in fact designed to initiate a process in which a wide range of stakeholders were to be involved in its re-contextualisation (FALUDI 2005, p. 107).

A second policy situation in which a compromise was found is the establishment of the "integrated polycentric territorial development" objective (Figure 2) in the participatory process that took place for the Green Paper of Territorial Cohesion (Commission of the European Communities 2008). The incorporation of "integrated" development has echoed two key scientific propositions made in the wake of the ESDP. A first argument emphasised the spontaneous mechanisms and voluntary cooperations in fostering the links that enable territorially-integrated strategies (DE BoE and HANQUET 2004, p. 132). To address the political dimension, the concept's governance storyline (Figure 2) not only earmarks the indispensable synergies between different policies, but also puts forth a context of dialogue between relevant actors that serves to champion the concept and win over the "non-believers" (BöHME and GLØERSEN 2011). A second relevant argument for integrated development concerned the maximising of synergies between the economic, socio-cultural, and physical environment. The expected outcome is to foster positive cross-externalities and build up resilience in the face of negative external challenges (European Spatial Planning Observation Network 2013, p. 76). This is an invitation to diversify and develop economies in rural areas while ensuring that non-central places benefit, rather than suffer from the consequences of agglomerations (European Spatial Planning Observation Network 2011, p. 33). Nonetheless, despite attempts to promote balance and cohesion, the "polycentric" side of the construct has very much remained subordinate to the globalised competitiveness argument sketched in the ESDP (see ibid., p. 27). Scholars have argued that the key challenge in transferring "balanced" ideals of spatial development planning 


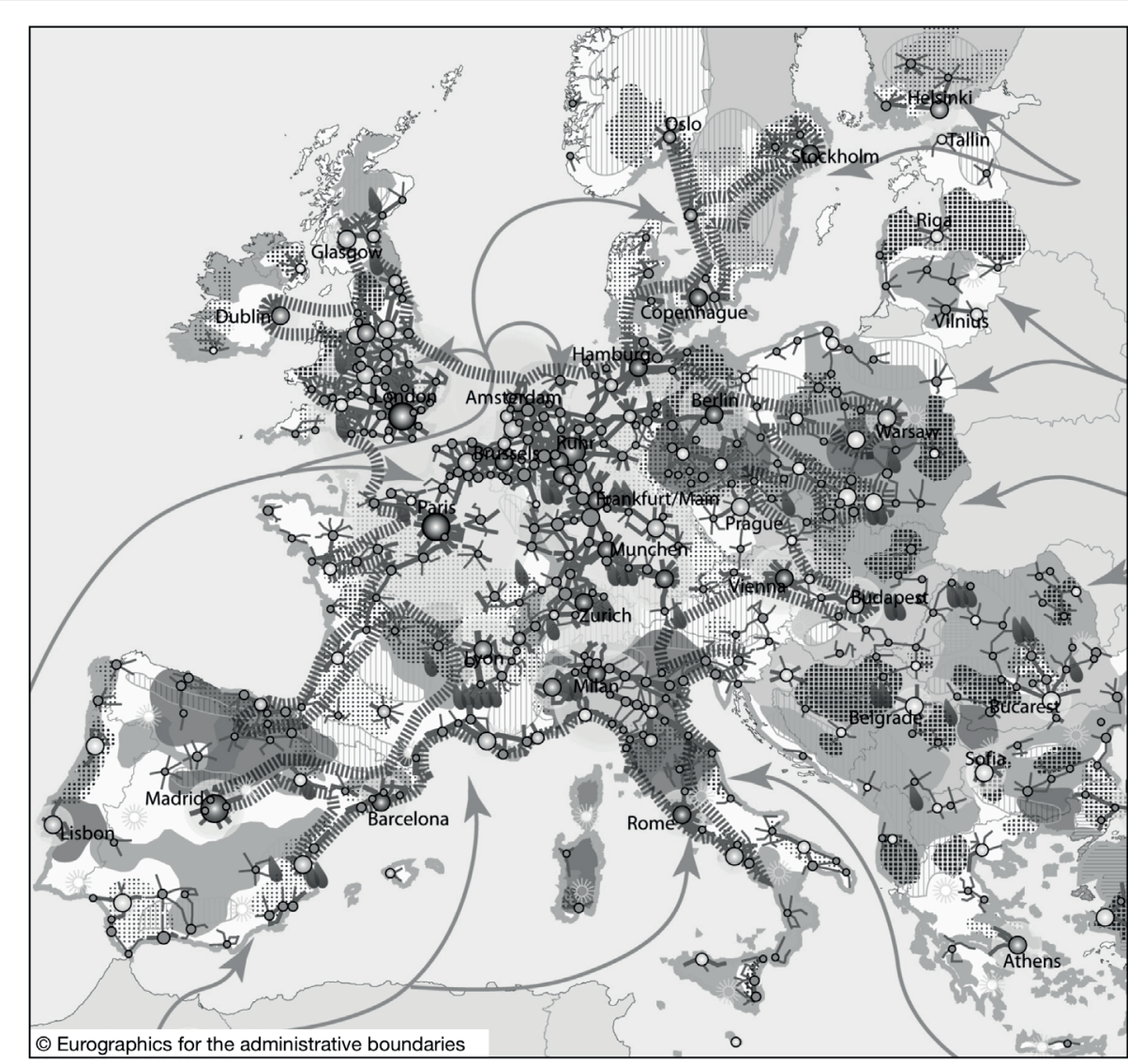

\section{Territorial Image of Europe by 2030 - Baseline Scenario}
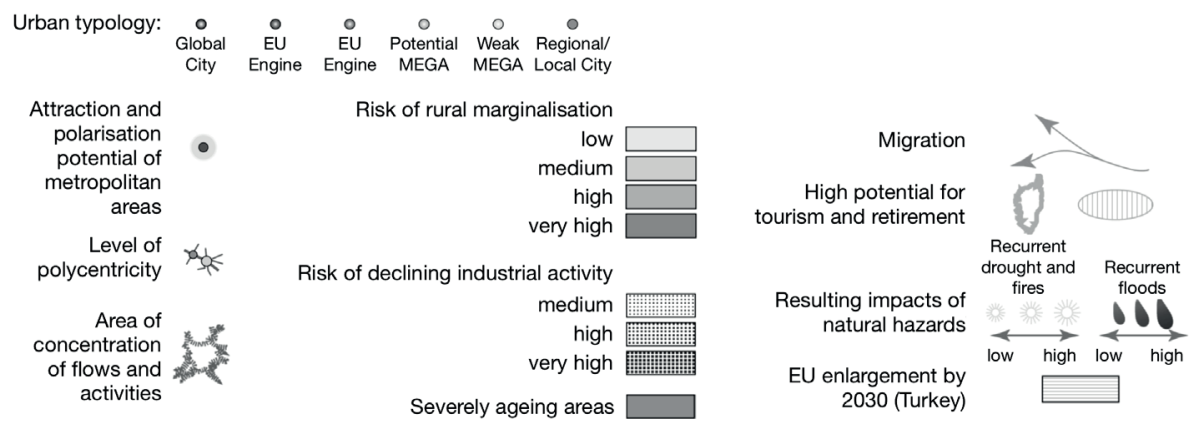

Source: Author's adaptation of European Spatial Planning Observation Network (2007, p. 64)

Figure 1: Map of the baseline scenario for territorial cohesion in the European Union by 2030 


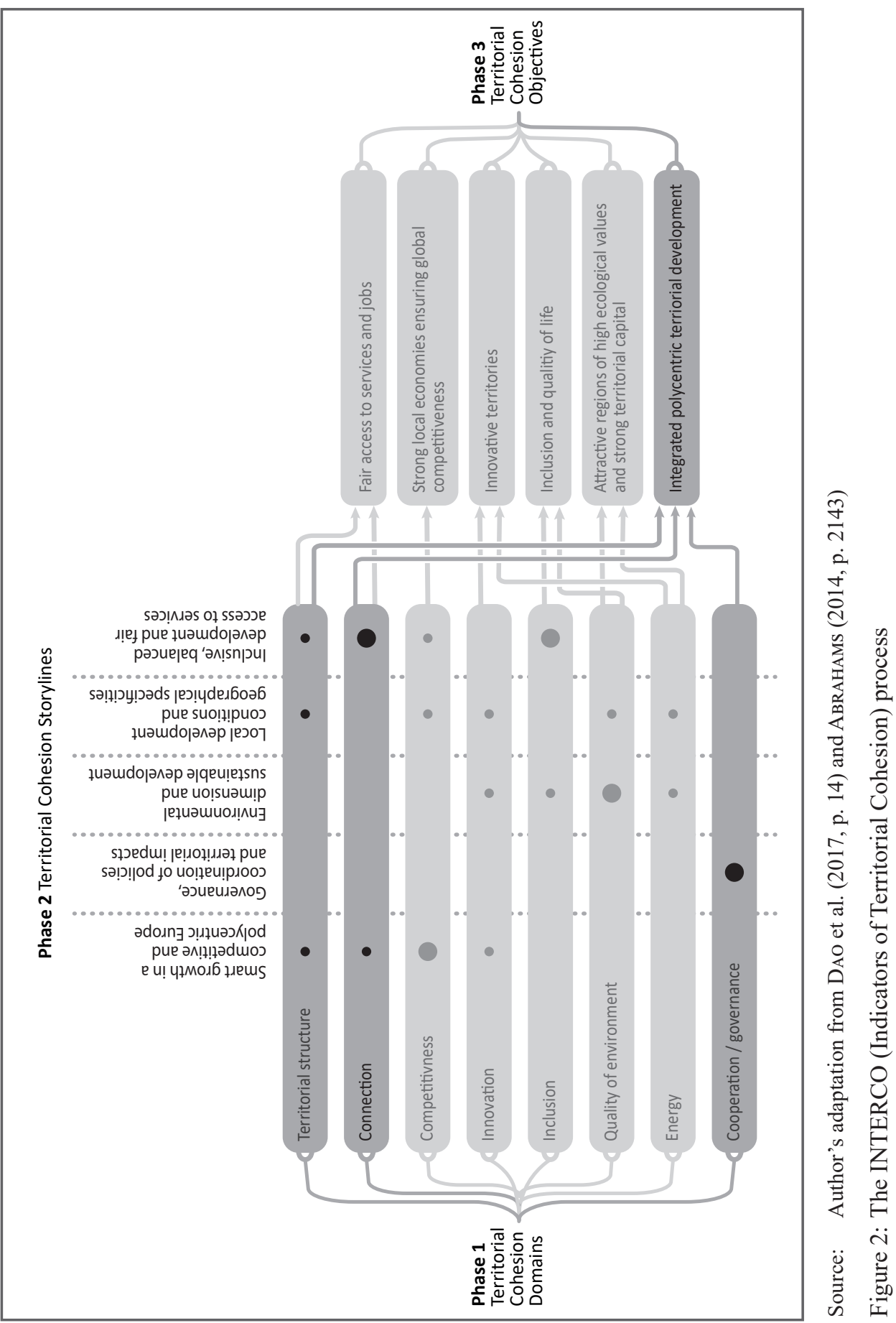


in the post-socialist SEE space lies in the weak capacity of the planning systems to seek agreements or compromises that disturb the pragmatic pursuit of economic growth in an imbalanced Europe (MAIER 2012, p. 148).

A third, more recent policy situation in which the dilemma of cohesion versus competitiveness has played out concerns the Cohesion Policy as a whole (and with it, territorial cohesion and integrated polycentric development). The marker for this is the "inclusive growth" idiom found in the "Europe 2020 Strategy". This juxtaposition is grasped as an indication of undoing the social concerns that have been part of the core argument underpinning territorial cohesion. The critical voices that put forth this claim highlight the replacement of "development" with "growth" in the Cohesion Policy's key narrative (SERVILLO 2010, p. 406; MEDEIROS 2016, p. 5). Another marker is the subordination of sustainable development to the ideal of "growth". This conceptual choice is grasped by critics as a key indicator of the neoliberalisation of territorial cohesion thinking, as it presents the overlapping of competitiveness with cohesion as conventional wisdom (VANOLO 2010, p. 1311). In other words, the dominant overarching argument is that cohesion is only possible if places (regions or localities) are competitive. In the context of a conceptual crisis of regional development theories (HADJIMICHALIS and HUDSON 2014), it appears that alternative conceptions of territorial cohesion have been by-and-large discouraged - e.g., well-being (JoNES et al. 2019, p. 113).

\subsection{Integrated polycentric development in peripheralising SEE contexts}

In this subsection, I shift my focus to the relevance of integrated polycentric development for peripheralised SEE regions. MALOUTAS points out that concepts tend to travel from institutional cores (in our case the EU) towards peripheries. Underpinning this transfer is the key assumption that "the periphery will experience in the future what the core has experienced in the past" (Maloutas 2018, p. 252).

Indeed, whereas the EU-15 Member States were able to actively contribute towards shaping territorial cohesion, the A-10 and A-2 States were rather in the position of distant learners, being at the time (early 2000s) in a full process of implementing pre-accession social and economic policy reforms (FARAGó and VARRó 2016). However, in the wake of the SEE Member States' accession, territorial cohesion was implemented with different degrees of enthusiasm (FALUdi 2010; MALÝ and MuLÍČECK 2016). As the EU lacks formal competence on matters of territorial development, but also in the light of an opaque, albeit gradual opening of the relevant decision-making processes (Davoudi 2005, p. 439; MENDEZ 2011), central governments became the key institutional actors in the reinterpretation of territorial cohesion.

Given this imbalance, the extent to which the concerns of the periphery of peripheries could be represented in constructing fuzzy concepts is questionable, even when the formal deliberative structures are in place. Political dependency can, for example, be reflected in the jurisdictional complexity required to operationalise territorial cohesion as part of the Cohesion Policy (see Churski and Perdal's study of Poland 2016). Moreover, certain terms can become devoid of their initially intended meanings. This is for instance the case 
of "governance", understood as more inclusive and long-lasting relations (see Figure 2). As part of the territorial cohesion construct, the term is designed to facilitate a rethinking of the role of central governments as a guarantor for smooth programme coordination, policy consistency, and strategic predictability (PARTRIDGE et al. 2015, p. 1320). Nonetheless, the proliferation of project-based competitive resource allocation has been shown not only to hinder these elements but also to strengthen the control that upper levels of Government have over development processes (COLOMB and SANTINHA 2014; GRUBER et al. 2019; Nemes et al. 2018).

In addition to organisational matters, the sedimentation of growth-pole thinking based on a model of concentrated trickle-down development (RAUHUT and HUMER 2020, p. 9) is likely to be the only rational response of Member States seeking to catch up with the core of the EU Single Market. Rapid gains in competitiveness and economic growth (MAIER 2012, pp. 144-147) might be an asset in responding to cyclical economic shocks that have been particularly hard felt in this part of Europe (see SMITH and TIMÁR 2010, pp. 118-119). As such, the expectation that central decision-makers ought to consider arguments for redistribution or decentralisation in a highly competitive broader context might be unrealistic.

Yet as far as balance is concerned, one of the fundamental challenges of applying the growth-driven competitive ideal in SEE spaces is its territorial morphology. To put it briefly, the SEE territory features more dispersed peripheral economic centres that are dotted around in vast areas with a high risk of rural marginalisation, declining industrial activity, and ageing (see Figure 1). In other words, there is a significant risk of establishing disconnected monocentric regional structures through visions that argue for a polycentric national structure.

\subsection{Interim conclusions}

To conclude this section, I would like to highlight two key points in the debate on territorial cohesion and polycentric development. A first point concerns the ambiguity of territorial cohesion and polycentric development in both academic (VAN MEETEREN et al. 2016) and political interpretations (RAUHUT 2017). The core issue appears to be the extent to which polarisation tendencies can be reconciled with cohesive and balanced development. The former appears to be an implied precondition for the latter. While this model is built on a rational, economy-driven interpretation of territorial development, its application at a member state level is unclear (RAUHUT 2017, p. 336).

A second point questions the extent to which integrated polycentric development can improve the socio-economic prospects within peripheralised areas. In so doing, this line of argument questions the potential need for auxiliary concepts that explicitly target the challenges that are experienced by these areas (HumER 2018). Nonetheless, as I will go on to argue in Section 5, rising disparities should not automatically be attributed to fallacies and inconsistencies of the territorial cohesion construct - after all, the term is purposely designed to be ambiguous. The wider policy and cultural context in which the term is applied, the mix of policy instruments, together with the political traditions 
in which policy gatekeepers operate are key factors that shape the applied meaning of the term and its ideals. It is for this very reason that a bottom-up analysis that is sensitive to planning cultures and practices is seen as one of the most promising ways of establishing what territorial cohesion ideals mean (SHAw and SyKes 2004; Demeterova et al. 2020b).

\section{An actor-centered conceptual framework for a bottom-up understanding of travelling policy concepts}

The conceptual framework underpinning my bottom-up analysis of integrated polycentric development follows an actor-centered approach grounded in an anti-foundationalist ontology. The centerpiece of this ontological perspective lies in the analyst's reluctance to employ reified aggregate concepts (such as "structure", or "institutions") when analysing human interactions. That is not to deny the existence of structures. Rather, anti-foundationalists argue that because human interactions take place in time-bound processual terms, it is essential that social science researchers are mindful of the emergent nature of human lived experiences (PRUs 1996, p. 18).

\subsection{Decentering policies and their political processes}

BEVIR and RHODES (2010) offer a promising anti-foundationalist approach to engage with the everyday agencies that shape policies in their decentered theory. The foundation of decentered theory gives value to the fact that social objectivity is contingent. It makes sense, regardless of one's ontological reasoning, to assume that the social world is always relative to the situations and practices in which it unfolds. BEVIR and RHODEs (2010) take this one step further by bringing policy communities' particularities to the forefront of the analysis.

To put it in Bevir and RHODES' (2010, p. 73) words, "[t]o decenter is to focus on the social construction of a practice through the ability of individuals to create and act on meanings. It is to unpack a practice as the disparate and contingent beliefs and actions of individuals". Decentered theory places meaning and agency at the core of political analysis. In other words, BEVIR and RHODES (2010) suggest that researchers should trace how large social and political entities are mediated, sustained, challenged, and changed through beliefs and actions (WAGENAAR 2012, p. 88). To do this, they argue that research ought to disaggregate grand political concepts and repackage them in common meanings rooted in contextualised webs of beliefs rather than in reified concepts (BEVIR and RHODES 2010, p.73). In their decentered theory, they conceptualise the state as an outcome of situated agency, practices, and power. On the other hand, they view institutions as the outcome of narratives, traditions, and dilemmas (see Table 1 for an overview).

BEVIR and RHODES (2010) seek to explain the episodic prevalence of structure, and its moulding through agency in contextually, time-sensitive systems of beliefs. In other words, any form of stable organisation (whether driven by a discourse, practice, an en- 
trenched set of beliefs, or enduring power relations) needs to be interpreted in-situ rather than explained mechanistically (cf. CAPANO and HowletT 2019). It must be contextualised rather than universalised and be understood as partially realised rather than applied to the latter.

\begin{tabular}{|l|l|}
\hline \multicolumn{1}{|c|}{ Concept } & \multicolumn{1}{c|}{ Concepts describing the state } \\
\hline \multicolumn{1}{|c|}{ Situated agency } & $\begin{array}{l}\text { Individuals' capacity to act. Agency is driven by contextualised reasoning } \\
\text { which is rooted in agents' webs of beliefs. Contextualised knowledge refers } \\
\text { to people's grasp of their own experiences and circumstances. This knowl- } \\
\text { edge is specific, concrete, and practical. }\end{array}$ \\
\hline Practice & $\begin{array}{l}\text { A set of stable actions that often exhibit a pattern which may remain relative- } \\
\text { ly stable across time. While being the consequences of actions, they cannot } \\
\text { explain actions, as people act contingently for reasons of their own. Practices } \\
\text { constrain the effects of an action, but do not necessarily constrain the beliefs } \\
\text { that people hold. }\end{array}$ \\
\hline Power & $\begin{array}{l}\text { On the one hand, power has an ideational dimension, referring to the way in } \\
\text { which traditions impact on individuals' beliefs helping to define them, their } \\
\text { action, and the world. On the other hand, power has an inhibiting dimension, } \\
\text { referring to the restrictive consequences of the actions of others in defining } \\
\text { what we can and cannot do. }\end{array}$ \\
\hline Narratives & $\begin{array}{l}\text { A form of explanation that works by relating actions to the beliefs and de- } \\
\text { sires that produce them. Narratives emerge from the conditional connections } \\
\text { between beliefs, desires, and actions and can be used to explain actions and } \\
\text { practices. }\end{array}$ \\
\hline Tradition & $\begin{array}{l}\text { The ideational background against which individuals come to adopt an } \\
\text { initial web of beliefs. Traditions can help explain why people hold the } \\
\text { beliefs they do but cannot fully explain actions. This is because people also } \\
\text { act on desires and beliefs, but also because people can innovate against the } \\
\text { background of a tradition. }\end{array}$ \\
\hline $\begin{array}{l}\text { Any experience or idea that conflicts with someone's beliefs, and therefore } \\
\text { forces them to alter the beliefs they inherit as a tradition. }\end{array}$ \\
\hline Soma
\end{tabular}

Source: Author's adaptation of BEVIR and RHODEs (2010, pp. 73-79)

Table 1: Key concepts in decentered theory

An upshot of BEVIR and RHODES' (2010) decentered approach is the separation between beliefs and practice. In other words, the actions which constitute a practice do not automatically alter individual beliefs. Actors exercise the freedom of undertaking an action, even though it does not align with their system of beliefs. Actors might choose to do so because the agency of the context they intervene upon would exhibit the least resistance (see also Griggs et al 2014). 
While generally well received in the interpretive policy analysis school, BEVIR and RHodes' (2010) approach has attracted its fair share of critique. MCANULLA (2006, p. 120) points out that their rejection of structure leads to an unsatisfactory account of the relationship between agents and context. Glynos and HowarTH (2008, p. 161) highlight that decentered theory "tends to encourage a far too mechanistic way of linking self-interpretations to background contexts and overemphasises the individual's creativity in coping with dilemmas by recourse to various strands of tradition". In their view, this raises a key question: why might some aspects of traditions exert greater appeal than others, or why might some aspects resist modification? Last, WAGENAAR (2012) argues that BEVIR and RHODES (2010) don't take practice seriously (he defines practice as the accommodation and resistance of the social world upon our actions). WAGENAAR's argument is that decentered theory sets out a performative conception of political science in a largely representative idiom.

One limitation in using BEVIR and RHODES (2010) decentered theory to guide my empirical work is rooted in their unclear conceptualisation of bureaucracy-bound political concepts. My experience in the field has been that interviewed actors tend to hit a wall of understanding when asked about their critical take on the assumptions underpinning a certain adopted strategy. "It's just the way it is," is often the most viable explanation. While this hints at the afore-mentioned breakage between beliefs and actions, it does little to explain the processes in which this breakage is rooted and the alternatives it suppresses. It is an indication that not only echoes GLYNOS and HowARTH's (2008) concerns, but also points out that "tradition" may indeed be an overburdened concept, to follow SMITH's (2008) critique. The direct implication for my research is the lack of an in-depth engagement with the political transformation process that resulted from the transfer of concepts which are external to the policy community in which they were applied. While this process is very relevant for understanding the selective up-take of territorial cohesion ideals, it appears attainable only through an ongoing engagement in the field through an action research approach.

\subsection{The relevance of decentered theory for understanding the interpretation of territorial cohesion}

Decentered theory focuses research on how policy intentions are embraced, crippled or opposed in their application contexts. Engaging with these processes is relevant because the use of ESI funds does not guarantee the transfer of EU policies (BACHTLER and MCMASTER 2008). The soft mechanism for transferring territorial cohesion opens up the possibility of deviation from the legal goals of the policy. This is especially the case in complex, intractable policy domains such as territorial development which rely on slippery policy goals such as reducing disparities (see for instance BENEDEK et al. 2019). Such goals, although enshrined in statute, are not quantified in irrefutable numbers, and are rather left to subjective interpretations. Moreover, as DABINETT and RICHARDSON (2005) show, the application of EU-backed spatial planning concepts (such as polycentricity) enables a process of rethinking spatial relations in which the meaning of key terms is likely to be contested. 


\section{Methodology}

This study focuses on territorial development policy processes in Romania overall and their manifestation in one of the country's eight NUTS-2 development regions - the North-West Region. I designed this paper as an in-depth qualitative study of a single case. I have defined the case as a policy community that is involved in implementing selected policy instruments that ought to contribute towards territorial cohesion in the NUTS-2 region. The instruments in question are LEADER-funded rural development initiatives, ERDF-funded urban development strategies, and regional development planning. In selecting the case and sampling respondents, my aim was to create the conditions for understanding how instruments that draw on the notion of territorial cohesion shape the shared knowledge and the relations between key actors relevant to territorial development.

I have based my selection of the North-West region on two criteria. First, it is a region that is representative of Romania's average development trends (Table 2). Internally, the region features a dispersed urban structure with polarising tendencies between the region's largest city (Cluj-Napoca) and the rest of the territory (see Figure 3; BLANKESPOOR et al. 2013, pp. 257-266; Agenţia de Dezvoltare Regională Nord-Vest 2014, p. 22). A second aspect was the accessibility in the field. This research was carried out as part of a $\mathrm{PhD}$ project within the RegPol ${ }^{2}$ Marie-Curie ITN network. ${ }^{1)}$ Through this, I was able to access

\begin{tabular}{|c|c|c|c|c|c|c|c|}
\hline \multirow[b]{2}{*}{ NUTS-2 Region } & \multicolumn{4}{|c|}{$\begin{array}{l}\text { Population and Social Dynamics } \\
\qquad(2007-2015)\end{array}$} & \multicolumn{3}{|c|}{$\begin{array}{l}\text { Regional Economics } \\
\qquad(2007-2015)\end{array}$} \\
\hline & $\begin{array}{c}\text { Change in } \\
\text { popula- } \\
\text { tion }\end{array}$ & $\begin{array}{c}\text { Trend of } \\
\text { average } \\
\text { migration } \\
\text { rate }\end{array}$ & $\begin{array}{l}\text { Change } \\
\text { of aged } \\
\text { depend- } \\
\text { ency }\end{array}$ & $\begin{array}{l}\text { Trend of } \\
\text { average } \\
\text { poverty } \\
\text { rate }\end{array}$ & $\begin{array}{c}\text { Change in } \\
\text { employ- } \\
\text { ment }\end{array}$ & $\begin{array}{c}\text { Change in } \\
\text { n percent } \\
\text { of nation- } \\
\text { al GDP }\end{array}$ & $\begin{array}{l}\text { Change in } \\
\text { GDP }\end{array}$ \\
\hline București și Ilfov & $1.5 \%$ & $4.2 \pi$ & $8 \%$ & $7.4 \% y$ & $6 \%$ & $134.3 \%$ & $43.9 \%$ \\
\hline Centru & $-0.4 \%$ & $-0.2 \pi$ & $10 \%$ & $18.0 \% \searrow$ & $-2 \%$ & $-28.2 \%$ & $16.4 \%$ \\
\hline Nord-Est & $0.7 \%$ & 0.3 & $-3 \%$ & $36.3 \%$ ע & $24 \%$ & $-29.9 \%$ & $15.1 \%$ \\
\hline Nord-Vest & $-0.4 \%$ & 0.3 ע & $8 \%$ & $19.6 \% \searrow$ & $17 \%$ & $-20.6 \%$ & $18.7 \%$ \\
\hline Sud-Est & $-2.2 \%$ & $-1.2 \searrow$ & $6 \%$ & $31.3 \% \pi$ & $50 \%$ & $-3.8 \%$ & $23.4 \%$ \\
\hline Sud-Muntenia & $-3.4 \%$ & -0.7 ע & $3 \%$ & $28.7 \% \pi$ & $29 \%$ & $-13.4 \%$ & $20.9 \%$ \\
\hline Sud-Vest Oltenia & $-4.4 \%$ & -1.8 ע & $4 \%$ & $34.5 \% \searrow$ & $61 \%$ & $-24.3 \%$ & $14.1 \%$ \\
\hline Vest & $-1.3 \%$ & $1.1 】$ & $8 \%$ & $14.8 \% \pi$ & $-9 \%$ & $-13.7 \%$ & $19.8 \%$ \\
\hline Romania Total & $-1.2 \%$ & $0.2 \pi$ & $5 \%$ & $25.0 \% \pi$ & $25 \%$ & I & $24.6 \%$ \\
\hline
\end{tabular}

Source: Data source: Institutul Naţional de Statistică, București [National Statistics Institute of Romania, Bucharest]; own calculation

Table 2: Key indicators used to guide the selection of the case study region

\footnotetext{
1) The $\mathrm{RegPol}^{2}$ project was a four year-long training network that researched issues of regional polarisation and socio-spatial peripheralisation in Central and Eastern Europe. More details can be found at www.regpol2.eu.
} 
information and contacts of the Babeș-Bolyai University and the North-West regional development agency which were members of this network.

Adopting a constructivist view, I understand territorial policy processes as relational, thus giving recognition to the fact that the key ideas underpinning policy practice are also shaped by actors who are external to the region in focus. This means that the aforementioned policy community expands beyond the regional boundaries - in this case to national policy-making institutions and their sources of expertise.

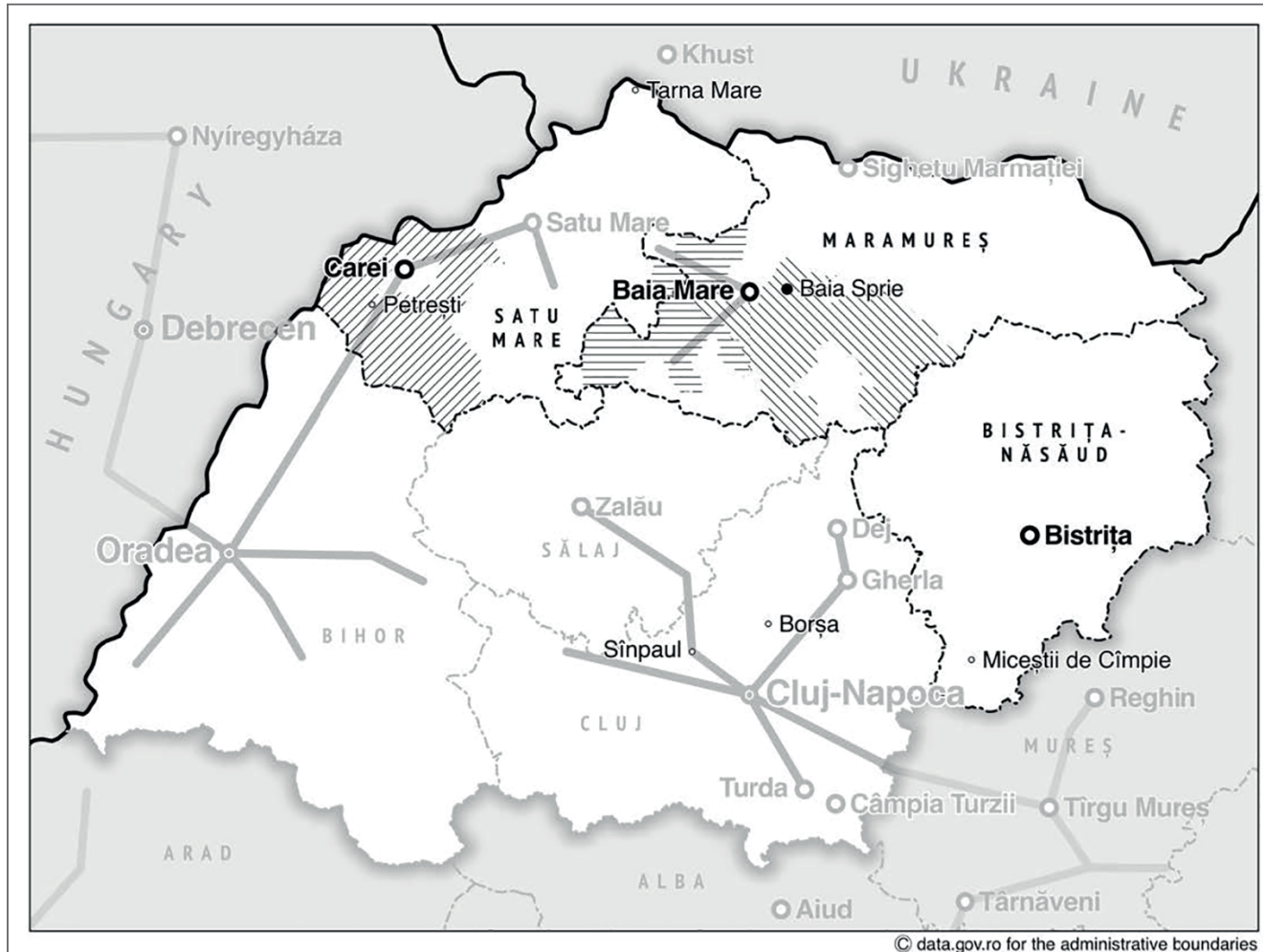

\section{Selected Areas and Localities in Romania's North-West Region}

\section{Localities \\ - Rank I city \\ - Rank II city \\ - Town \\ - Village (selected)}

Selected places are marked in dark text, other places are dimmed out.
Borders

- National Border

--- County Border

Polycentricity (cf. Figure 1)

Level of polycentricity
LEADER Regions (selected)

NIV Mara-Natur

三 Maramureș Vest

IVI, Sud-Vest Satu Mare

Source: Own design (source for the administrative boundaries: (C) data.gov.ro)

Figure 3: The case study area in the North-West region of Romania 
It is important to recognise that not all meanings find their way to the relevant policy community. Actors might systemically or episodically find the "core" community inaccessible (HERRSCHEL 2011). My intention in conducting this research was therefore not to capture a broad range of policy meanings and the multiple traditions in which they are rooted, but rather to bring forth the most relevant ones. In short then, I must point out that this research sheds light on a provisional milieu of situated multilevel interactions.

In collecting and analysing the data, I have followed a number of grounded theory principles. Ever since its introduction by GLASER and STRAUSS (1967), grounded theory has been segmented into multiple strands of understanding and implementation to the point that there is no consensus on a unitary grounded theory approach. Underpinning this fragmentation have been divergent takes on the researcher's position vis-a-vis the field, on the degree of sensitivity to the context, or on the handling of the collected data - to name but the most prominent debates. Put shortly, grounded theory doesn't offer a prescribed framework for collecting or interpreting empirical material, neither does it enable high-level theorising on the studied phenomenon. Following Charmaz (2006), I see the methodology's key strongpoints as four-fold: the avoidance of imposing theory-driven categorisations; the ongoing adaptation of the theoretical framework to the field; the flexible approach towards conducting the fieldwork; the ongoing comparison between data. These four principles have been at the core of my methodological design.

I conducted my empirical research through a mix of document analysis and semi-structured expert interviews. The former was a two-tiered process that, on the one hand sought to analyse the integration of territorial cohesion and integrated polycentric development in national policies (see Table 4). On the other hand, I analysed the local and regional development strategies to which the interviewed experts have contributed. This analysis was primarily focused on the incorporation of the territorial cohesion objectives (see Figure 2) in the document's socio-economic analysis, SWOT matrix, and definition of intervention fields. The role of this analysis was to structure the interview's core discussion points. In turn, the interviews targeted the constitutive motives, world views, norms, and implicit beliefs that underpin specialist knowledge (following BogNER and MENZ 2002, p. 38).

Interview partners were sampled on the basis of their institutional role and the location of their institution. A first sampling criterion was the person's involvement in regional development planning. A second criterion targeted actors from urban areas (preferably small to medium cities) that implemented an integrated urban development plan in the 2007-2013 multi-annual financial framework and their adjacent LEADER regions. The rationale was to explore the interplay between ESI-funded territorial development instruments. Pursuing this criterion to the letter was not possible due to a lack of access in the field. Third, I have sampled key actors from non-central areas that were successful in attracting ESI funds. In addition to these three criteria, I used snowballing to reach further participants at the local-regional level and at the national level. I conducted a total of 27 interviews in early 2017 and between January and April 2018 (see Table 3 for details about quoted interviews). 


\begin{tabular}{|l|l|c|l|l|}
\hline No. & \multicolumn{1}{|c|}{ Date } & $\begin{array}{c}\text { Length } \\
\text { (min) }\end{array}$ & \multicolumn{1}{|c|}{ Role of interviewed person } & \multicolumn{1}{|c|}{ Documentation } \\
\hline 1 & April 2018 & $48: 42$ & academic, former governmental advisor & transcript of recording \\
\hline 2 & March 2018 & $92: 47$ & local politician, rural local authority & transcript of recording \\
\hline 3 & April 2018 & $32: 37$ & former minister & transcript of recording \\
\hline 4 & February 2017 & $\sim 2$ hours & former regional development expert & notes \\
\hline 5 & January 2017 & $\sim 1$ hour & former governmental civil servant & notes \\
\hline 6 & April 2018 & $58: 20$ & local and regional development consultant & transcript of recording \\
\hline 7 & April 2018 & $44: 57$ & academic, former governmental advisor & transcript of recording \\
\hline 8 & April 2018 & $71: 37$ & regional development policy expert & transcript of recording \\
\hline 9 & February 2018 & $101: 17$ & former governmental civil servant & transcript of recording \\
\hline 10 & February 2018 & $56: 00$ & local politician, rural local authority & transcript of recording \\
\hline 11 & February 2018 & $98: 08$ & regional development consultant & transcript of recording \\
\hline 12 & February 2018 & $57: 52$ & civil servant in a small town & transcript of recording \\
\hline 13 & February 2018 & $73: 22$ & former politician of a small town & transcript of recording \\
\hline 14 & March 2018 & $70: 49$ & civil servant in a medium-sized town & transcript of recording \\
\hline 15 & April 2018 & $\sim 1$ hour & governmental civil servant & notes \\
\hline 16 & April 2018 & $48: 28$ & academic and government advisor & transcript of recording \\
\hline & & & & \\
\hline
\end{tabular}

Table 3: Details about the interviews that have been quoted in this paper

\section{Decentered perspectives on Romania's growth pole-driven polycentric development approach}

In the second section I pointed out that in spite of its ambiguity, the ideal of integrated polycentric development is strongly oriented towards enabling competitiveness through concentrated economic growth. On the other hand, arguments for cohesion and balanced development have been by and large underrepresented.

The aim of this section is to explore the context in which the priorities for polycentric development policies are established, to detail the key narratives underpinning these policies, and to outline the territorial governance practices which these policies aim to shift. To kick off the discussion, I have summarised the key policy documents that engage with the notion of polycentric development in Romania (see Table 4). As the literature suggests, Governmental policy narratives give an unclear treatment of polycentricity (HUMER 2018). Romania is no exception. This unclarity manifests itself through the continuous adaptation of the polycentric approach in the development narrative at the national scale. In the meantime, the understandings of polycentricity that target the regional and sub-regional levels tend to envisage a growth pole-driven development scenario. My goal in what follows is to highlight that this outcome is not entirely the product of a systemic rational design. Rather, it is also tightly linked to the evolution of decision-making traditions and practice-bound applications of the ideals conveyed through polycentric development. 


\begin{tabular}{|c|c|c|c|}
\hline Year & Document Name & Author & Grasp of Polycentric Development \\
\hline 2001 & $\begin{array}{l}\text { Planul de Amenajare a Teritori- } \\
\text { ului National, Sectiunea a IV-a } \\
\text { [The } 4^{\text {th }} \text { Section of the National } \\
\text { Spatial Plan] }\end{array}$ & $\begin{array}{l}\text { Romanian Parlia- } \\
\text { ment }\end{array}$ & $\begin{array}{l}\text { Polycentricity is not mentioned. The term } \\
\text { "network of localities" is used to describe an } \\
\text { assemblage of development relations in the } \\
\text { political, administrative, socio-cultural, or eco- } \\
\text { nomic spheres. Metropolitan areas are seen as } \\
\text { a balancing mechanism between big cities and } \\
\text { their hinterlands up to a distance of } 30 \mathrm{~km} \text {. }\end{array}$ \\
\hline 2007 & $\begin{array}{l}\text { National Strategic Reference } \\
\text { Framework for Romania } \\
\text { (NSRF) 2007-2013 }\end{array}$ & $\begin{array}{l}\text { Ministry of Econ- } \\
\text { omy and Finance }\end{array}$ & $\begin{array}{l}\text { Support urban poles by promoting rapid } \\
\text { growth, creating jobs, boosting productivity } \\
\text { and generating positive spill-over effects in } \\
\text { the surrounding areas. Metropolitan areas, de- } \\
\text { velopment corridors, and urbanised rural areas } \\
\text { to promote territorial cohesion by halting and } \\
\text { reversing widening regional disparities. }\end{array}$ \\
\hline 2007 & $\begin{array}{l}\text { Programul Operațional Region- } \\
\text { al 2007-2013 [Regional Opera- } \\
\text { tional Programme 2007-2013] }\end{array}$ & $\begin{array}{l}\text { Ministry of } \\
\text { Development, } \\
\text { Public Works, } \\
\text { and Housing }\end{array}$ & $\begin{array}{l}\text { Describes a polycentric regional development } \\
\text { approach that targets regional and local urban } \\
\text { growth poles while also seeking to improve } \\
\text { urban-rural links. }\end{array}$ \\
\hline 2008 & $\begin{array}{l}\text { Response to the Consultation } \\
\text { on the Green Paper of Territori- } \\
\text { al Cohesion }\end{array}$ & $\begin{array}{l}\text { Romanian Gov- } \\
\text { ernment }\end{array}$ & $\begin{array}{l}\text { Polycentricity is not mentioned in the re- } \\
\text { sponse. Rather, the competitiveness argument } \\
\text { of the first INTERCO storyline (see Figure } \\
\text { 1) is linked to utilising each territory's own } \\
\text { development potential. }\end{array}$ \\
\hline 2013 & $\begin{array}{l}\text { Fundamentele Procesului } \\
\text { Actual de Regionalizare a } \\
\text { României [The Premises of } \\
\text { Romania’s Current Regionali- } \\
\text { sation Process] }\end{array}$ & $\begin{array}{l}\text { Advisory Council } \\
\text { for Regionalisa- } \\
\text { tion (CONREG) }\end{array}$ & $\begin{array}{l}\text { Administrative devolution stimulates a } \\
\text { balanced polycentric regional development. } \\
\text { Polycentricity results from an ongoing com- } \\
\text { petition between cities. Although desirable, } \\
\text { polycentric systems tend to co-exist with } \\
\text { mono- and bi-centric ones. }\end{array}$ \\
\hline 2014 & Partnership Agreement & $\begin{array}{l}\text { European Com- } \\
\text { mission }\end{array}$ & $\begin{array}{l}\text { Mentions the economic dimension of } \\
\text { polycentric development which is attached } \\
\text { to the growth pole strategy. These poles' en- } \\
\text { dogenous resources could be used for public } \\
\text { investment projects in lagging areas. }\end{array}$ \\
\hline 2014 & $\begin{array}{l}\text { Programul Operațional Region- } \\
\text { al 2014-2020 [Regional Opera- } \\
\text { tional Programme 2014-2020] }\end{array}$ & $\begin{array}{l}\text { Ministry of Re- } \\
\text { gional Develop- } \\
\text { ment and Public } \\
\text { Administration }\end{array}$ & $\begin{array}{l}\text { Together with territorial specialisation, } \\
\text { polycentric development is used as a guiding } \\
\text { principle for consolidating the country's urban } \\
\text { network. The policy targets not only growth } \\
\text { poles but also smaller cities (i.e., county } \\
\text { seats). Introduces concepts of functional urban } \\
\text { areas and urban-rural partnerships }\end{array}$ \\
\hline 2015 & $\begin{array}{l}\text { Strategia de Dezvoltare Ter- } \\
\text { itorială a României [Roma- } \\
\text { nia's Territorial Development } \\
\text { Strategy] }\end{array}$ & $\begin{array}{l}\text { Ministry of Re- } \\
\text { gional Develop- } \\
\text { ment and Public } \\
\text { Administration }\end{array}$ & $\begin{array}{l}\text { Four key principles of a polycentric develop- } \\
\text { ment scenario: concentration, connectivity, } \\
\text { cooperation, and coordination. These are } \\
\text { augmented by coherent investment and } \\
\text { planning policies. Polycentricity implies the } \\
\text { concentration of human, material, technologi- } \\
\text { cal resources in large and medium cities. }\end{array}$ \\
\hline
\end{tabular}

Table 4: Analysed national policy documents 


\subsection{Decision-making practices}

The political stance of the Romanian state to territorial development has been shaped by two antithetical processes. On one hand, there has been a tendency for keeping the centralised decision-making patterns of the Communist administration. Complementing this has been an ongoing process of governmental devolution that was in full swing between 2007 and 2013 (STĂNESCU 2015, p. 76). Rather than overhauling existing practices, the European Union's influence upon territorial development has been episodic and, in some cases, serendipitous.

In this context, a first, perhaps most prominent key practice that shapes territorial policies is the hyper-localised focus of their making. To put it in the words of a former governmental advisor, the process that emerged is akin to a problem child: "County leaders' indispensable role in election campaigns has created a pyramid-like structure which pushes Members of Parliament to tailor the national legislation to the very specific needs of the communities they represent" (Interview No. 1). At the face of it, this remark points at the obvious process of political bargaining. Nonetheless, these negotiations are rooted in a web of dependency relationships between the local and the county level - the latter is highly dependent on accessing central funds to which in most cases the former acts as a more or less visible gatekeeper. In an increasingly polarised socio-economic development context, the matter of fair access to services (see Figure 2) tends to be used as a bargaining chip to ensure local leaders' compliance (interview No. 2). To be clear, seen from the periphery, "fair access" is in most cases about survival - that is, local authorities' abilities to discharge of their duties. All in all, the quest for compliance within the lower levels of government has systemically blocked attempts of integrative administrative reforms (e.g., regionalisation, sharing of administrative capacities) while also slowing the implementation of national territorial visions and regional economic development strategies (interviews No. 3 and 4).

The European Commission's promotion of polycentric development was primarily carried out through budgetary concentration. This materialised as a priority axis in the 2007-2013 Regional Operational Programme that was reserved for the designated growth poles (see Subsection 5.2). Other domains (most prominently infrastructure and competitiveness-enhancing measures) were treated as sectoral policy issues ${ }^{2)}$ whose territorial integration was by and large left to the eligible applicants in a vacuum of expertise (see Subsection 5.4).

The aforementioned relations of dependency are however not hegemonic and can be reversed, albeit episodically. Underpinning this fragility is a second key political practice of situated agreeableness. In practical terms, when organised in a common voice, the sheer number of local leaders in Romania (3181, 2685 of which are leaders of rural authorities) is enough to ensure sufficient visibility in shaping governmental policy. Attempts to coordinate territorial development tend to succumb to this practice that typically targets ancil-

\footnotetext{
2) All the ESI-funded policy goals were transposed in Sectoral Operational Programmes that only marginally considered territorial specificities (most of the time by drawing on broad generalisations - e.g., rural vs. urban spaces, well developed vs. less developed regions).
} 
lary legislation - e.g., the public finances law. ${ }^{3)}$ In light of this fragile balance of political power, strategic programmes (e.g., ESI-funded operational programmes) tend to pursue a high number of, typically only partially fulfilled, goals. This indecisiveness and proclivity towards episodic changes in strategy has prompted the European Commission to be hesitant in accepting new proposals and priorities until the assumed ones (some dating from 2007 - e.g., nation-wide transport infrastructures) are fulfilled (interview No. 4). Issues of territorial cohesion beyond the national level have thus largely been sidelined.

A third and final key practice that links to the ones above concerns leadership. Leaders of public organisations are typically put in a position of extremely high responsibility and henceforth seek to exert as much control over the decision-making process as possible. This however is not always possible, for leaders often have to grapple with a complex institutional setting that although theoretically subordinate to them can be beyond their control. The interview data indicates that public servants are in a position to exert significant influence on the formal information flow directed to the leader (interview No. 5). Other instances of this phenomena show that the pursuit of new development strategies depends not only on leaders' readiness to alter their own web of beliefs but also on their willingness (be it as a minister or a mayor) to pursue system-disrupting and politically risky decisions. The examples are varied and range from organisational reshuffling to taking unpopular decisions - e.g., raising local taxes to create a budget for co-financing ESI-funded integrated interventions (interview No. 13).

All in all, the blend of hyperlocal policy orientation, situated agreeableness, and challenged leadership creates a fundamental problem of coordination both at a governmental and at lower levels of decision making. In the case of the former, the interviews highlight seemingly insurmountable difficulties in the coordination between Ministries' own agencies and departments. In the case of the latter, the systemic coordination problem results in an overly burdened local level that is not coordinated on a supra-local level. An example from a county is very telling: "The regional level was focused on ESI funds, the county council on rural development, and the cities mostly sought to take care of their infrastructure. These strategic lines didn't intersect and moreover, those making the strategies were not really in touch with each other" (interview No. 6).

The depicted state of affairs shows an imbalance in the policy transfer logic. On the one hand, the idea of concentrated polycentricity from an EU perspective has travelled well into national policy documents. On the other hand, the balance/integrated arm of the concept studied here has been kicked down the territorial and institutional layers without much support offered (if any at all) for understanding it. Overwhelmingly, the data shows that institutional actors who sought to concern themselves with this latter matter did so at their own initiative.

\footnotetext{
3) A telling example is the undermining of the goals set in the national planning legislation that seeks to limit urban sprawl and focus new developments within built-up areas (Legea No. 350/06.07.2001). This provision remains in place to this day. However, the budget transfer law was changed in 2006 from being 100 percent population based to 75 percent population and 25 percent built-up area (intravilan). This shift occurred at mayors' insistence, was unopposed by national decision makers, and was swiftly followed by an increase in the designated built-up areas (a prerogative of local administrations).
} 


\subsection{Narratives of polycentric regional economic development}

Both in the 2007-2013 and 2014-2020 multiannual financial framework (MFF), ${ }^{4)}$ the narratives of regional economic development are typically constructed in relation to the ESI-funded Regional Operational Programme. The urban development priority axis of this operational programme has been the central locus of discussions concerning polycentric development at a regional level, and a field in which two contrasting narratives intersect - a concentrated and a devolved growth pole one.

The idea of concentrated growth pole development was promoted by both the World Bank and the European Commission. At its core, the narrative is shaped by a modernisation discourse that ties the development of Romania's urban centres to the country's peripheral position within the Single Market. To overcome this status, the argument goes, ESI-funded interventions should aim for a more competitive, more innovative, and better connected economy (see Ministry of Economy and Finance 2007; BLANKESPOOR et al. 2013). Moreover, these interventions ought to be thematically and territorially concentrated. Drawing on these vague principles, the 2007-2013 Regional Operational Programme designated eleven urban growth poles and thirteen development poles that were granted access to dedicated budgets (Hotărârea Guvernului No. 998/2008). The selection of these localities as "poles" has become a generally accepted position between experts, on the basis that the "science behind it was sound" (interview No. 7). Adding to this, the supporters of this narrative emphasise the inapplicability of the balanced development storyline with the basic normative position that "some [individuals, business sectors, and territories] work out better than others, regardless of how many resources you pump in one or the other" (interview No. 8).

When put into practice, the above described policy narrative gradually acquired a less strategic, and more polarised nuance. From an economic development viewpoint, the resulting implementation was predominantly neutral (i.e., not sector specific or tied to an economic strategy), and horizontal (i.e., seeking to fund as many interventions as possible). The use of territorial cohesion in general, and polycentricity in particular, gave the regional development narrative a localised flavour by emphasising prominent local leaders' political meanings (see RAUHUT 2017). As such, a vague policy goal of increasing urban life quality was used to contextualise polycentric development. Growth and development poles also kicked-off place marketing strategies and strengthened (in a more or less sporadic fashion) their key local economic development sectors (e.g., the IT sector in Cluj-Napoca). This policy narrative focused almost exclusively on the large cities (Rank II cities) and was generally oblivious to the broader regional context.

The situations that shaped this narrative in practice were for the most part localised expressions of policy implementation challenges. For one, a significant number of public administrations were unprepared to manage funds to which they were granted access. The issue became more obvious in the growth and development poles that had access to higher budgets. Given this, the selection of projects was neither strategic nor tied to a vision. It was rather pragmatic, with priority given to initiatives that could be financed quickly and

\footnotetext{
4) The MFF is the European Union's seven-year budgeting period.
} 
effortlessly (interview No. 1). The assumption that large cities could manage large budgets by virtue of their size appeared to have been misguided at the outset.

A second aspect was that the centralised conceptualisation and implementation of the Regional Operational Programme was oblivious to the variegated contextual factors that defined the urban poles and their hinterland. In this matter, the issue of territorial capital became a salient "ally" for integrated polycentric development. However, while this conceptual link was faithfully quoted in a significant number of strategic plans, it gained little practical recognition in shaping the competitiveness dimension of territorial cohesion to territorial specificities. As a result, the territorial rationale behind public investments (funded both through ESI as well as national funds) was half-baked: "The public authority is aware that [public investments] aid development, because they facilitate access to information, work force mobility, resources, etc. But you need to make these territorial relations lucrative for linking resource pools to processing capacities and further to markets" (interview No. 9). The lack of interrelations between a strategy targeting the territorial capital and one targeting competitiveness resulted in the acceleration of concentrating tendencies within the designated poles. Other urban centres began developing a feeling that they were losing out: “At the beginning we said: 'let's have regional trains'. No, all of them had to run through Cluj[-Napoca]. [...] Then our university was taken over [by a university in Cluj-Napoca] and we concentrated all major regional projects there through awkward conditions in the applicant's guide. You get the feeling that these bluffs are intended to impose serfdom" (interview No. 11).

In addition to the space-blind implementation of territorial cohesion at a regional scale, urban poles have also tended to dominate their immediate hinterland (see DRANCA 2013) and forge cooperations and political and strategic alliances with other large cities. In a context of omnipresent salient deficits, the growth pole narrative legitimised the earmarking of the poles' urgent problems as more urgent. This one-sided grasp of the modernisation narrative took over as the much-debated national regionalisation narrative that sought to construct functional regions around these poles failed to gain traction. Moreover, regional development agencies were denied the competence to intervene upon strategic planning issues, leaving coordinated regional approaches devoid of meaning (interview No. 4). As I will show in Subsection 5.3, this opened avenues for power concentration in urban poles.

Practice has it, that in a void of a coordinated regional approach, the designated poles have become placeholders for a market and network-driven interpretation of regional development. Given the lack of clear strategic spatial planning (nota bene, not land use planning) instruments beyond the local level, a peculiar development has been the proliferation of economic clusters as mechanisms for coordinated regional development. A decisive contributing factor has been the active involvement of the regional development agencies in kick-starting such structures.

In a direct response to concentrating development trends, a devolved growth poles approach was introduced in the 2014-2020 Regional Operational Programme, raising the number of targeted cities from 24 to 42 - this includes all county capitals. The key idea was a more balanced redistribution of funds. I must point out that while not directly linked to it, the approach mirrors the National Local Development Programme discourse of "no place left behind", albeit on a different scale. Beyond this, the devolved approach is underpinned 
by key cognitive policy ideas that earmark agriculture and tourism as key domains for economic, social, and territorial cohesion in predominantly rural areas (interview No. 8).

Attempts to bridge the concentrated and growth pole narratives by pursuing a territorially-integrated rather than a purely administrative policy logic were unsuccessful - as an expert recalls, the conclusion of the debate was “we agreed that we don't agree, and that was it" (interview No. 8). The beliefs underpinning these two positions are intractable, belonging to different schools of academic thought (the former based on the World Bank's $3 \mathrm{D}$ model and new economic geography, the other drawing predominantly on an export base theory). These diverging backgrounds of understandings have generated a political struggle over defining the national strategy and have been playing themselves out episodically as a discord between nationally-funded instruments and ESI-funded operational programmes.

\subsection{The governance narrative and the trust conundrum}

In territorial development policy making, governance models are approached as normative prescriptions for the opening of the governmental decision process to a broader spectrum of stakeholders. At a governmental level, the establishment of the Lisbon Agenda-inspired governmental working groups (see MENDEZ 2011) was a very visible change. Similar consultative processes were established at a regional level too. However, these new structures did little to kick-off a broader debate in which fuzzy concepts could be demystified or re-interpreted. While heterarchical networks have emerged episodically, interviewed experts have overwhelmingly described the strongly centralised institutional hierarchies as overwhelming and inappropriate for reinterpretations. This has posed significant barriers for defining the "integrated" branch of "integrated territorial development".

A situation that has stalled the spread of development beyond growth poles was the (still) partial realisation of metropolitan areas. Here, coordination has been earmarked as one of the initial intentions of these structures (i.e., a means of binding polycentric cities to their surrounding territory). Yet in both types of metropolitan areas, coordination has been re-purposed in practice as financial domination. For one, the growth poles designated for the 2007-2013 Multiannual Financial Framework MFF (e.g. Cluj-Napoca in the NorthWest region), pursued a strategy that has almost entirely focused on increasing the city's visibility in the EU Single Market. Nonetheless, despite introducing regional development plans (as conditioned by the European Commission), the coordinating offices of the metropolitan areas were typically understaffed and underfunded (interview No. 8). To put it in the words of the mayor of a village, belonging to such a structure "hasn't meant anything for us. [...]. As far as I understand, our development depends on the growth pole [pause]. Perhaps our turn will come at some point in the future" (interview No. 10).

On the other hand, a second category of metropolitan areas has been created as voluntary associations for delivering public infrastructures. The example shared by a policy expert in a medium-sized city is telling of the working principles that drive these structures: "[Funds were available] to rebuild the drinking water and sewage infrastructure. $[\ldots]$ The theory was that we get our own distribution system and have some cohesion [in 
the region]. [...] When [all the surrounding local authorities] entered the scheme, they were asked to close their own systems, so we can run it together, install filters and so on. The costs were so high, that when the system was later expanded [...] the existing members said: ok, will you pay me for the water that's running in my system, just as I pay to have my water filtered? These new members couldn't afford it. And the war is still ongoing." (interview No. 11). This example shows that new governance mechanisms did not help overcome the individualistic development practices but rather deepened them. Depicted above is a worst case of furthering peripheralisation by putting actors in a situation that is disadvantageous (e.g., higher utility costs) and which they cannot control on their own. The unintended consequences stemmed from a lack of understanding of the context in which infrastructure sharing was promoted. New policy mechanisms that drew on the polycentricity ideal were designed with the assumption that actors would act rationally when incented to do so. These mechanisms have failed to respond to competition-centred localised political traditions and have lacked the mechanisms for a gradual adaptation.

In addition to this, the proliferation of voluntary metropolitan areas has done little to create urban-rural relations in predominantly rural areas. Quite to the contrary, it seems that highly successful small towns have built strategies and project portfolios that ignored their membership in such structures. As an expert from a small town reflects, "we never secured funding [together], we were seldom invited to participate, and when we were, the projects never materialised. So we are mostly on our own" (interview No. 12).

The narrative provided in the policy failed to address localised practices of power concentration, and rather contributed to their accumulation in the growth and development poles (power here is seen as the restrictive consequences of the actions of others): "We had a strategic evaluation committee. When there were a lot of projects submitted, our job was to prioritise them. [Prominent politician name] got rid of this committee, arguing that it was pointless [...]. By doing this, every decision taken at the regional level became political $[\ldots]$ so things got pretty simple for the civil servants: your boss now tells you directly what you need to do" (interview No. 11).

The processes described by the interviewed experts highlight that the narrative of introducing new governance regimes has been one of compulsion, a condition attached for receiving funds. This doesn't favour the creation of situations in which actors adjust their webs of beliefs beyond accommodating these new formal requirements. Yet places that could adapt to these requirements were swiftly faced with a systemic barrier that has prohibited them to implement policy instruments in accordance with their needs. A former local politician recalls the reaction of governmental policy designers in discussions concerning the financing of LEADER Local Action Groups through multiple operational programmes:5) "They were probably afraid to let us do it. The argument was along the lines of: 'you weren't able to use one operational programme, and now you're telling me that you'll use three?' The ministries were somewhat suspicious, and they were probably right. Only a handful of local authorities could have made the connections between these three funds. But why not allow those willing to do this to try" (interview No. 13). Ultimately,

5) This mix of financing lines has been disallowed in Romania. 
this reluctance boils down to a lack of trust between the different authorities involved in policy delivery. Seen from below, this looks like an "eternal blaming game about who sabotages the system: those in the Government say that the local level is lazy. Those at the local level say that the conditions are too demanding to be realistically met" (interview No. 14). Seen from above, those managing the programmes are put in a position to devise conditions that apply across the country (interview No. 15). This creates a fundamental issue, because, as pointed out in Section 2, territorial cohesion ideals were designed to be debated and applied at a local-regional rather than at a central level.

\subsection{Transferring territorial cohesion knowledge and potentials for political dependency}

Territorial cohesion and its subcomponents come across as highly normative concepts. The construct enables actors to derive a model of society from the traditions shared by their political community and structure a guiding metaphor about how the world ought to work. However, Romania's case shows that territorial cohesion is of little cognitive value - it provides few (if any at all) useful solutions for charting a clear and specific course of action to achieve normative ideals. ${ }^{6}$ ) As a general remark, the concept appears to be entangled in the strategic spatial planning versus regional development debate, with all the intractable issues that surround the debate - e.g., flexibility vs. predictability, top-down vs. bottom-up, or issues of jurisdiction, to name but the most prominent.

The Romanian case shows that the polycentric development narrative has been encapsulated in the regional development narrative and used to justify GDP-enhancing processes of polarisation. While a select number of cities have undoubtedly benefited from this approach (as indeed intended), the spread of these benefits to their territorial hinterlands is less than apparent. My data suggests that this is due to an ongoing ousting of a series of concepts that are ancillary to the notion of polycentricity. This has led to the instatement of practical barriers of political understanding concerning the strategic decisions to be made, leading to a loss of clarity over who ought to take responsibility for coordinating supra-local strategic planning.

With coordination sidelined, the key marker of successful economic development has become rigorous project management and accessing as many funds as possible. The entrenched belief is that fulfilling the latter condition automatically improves development prospects which will eventually enhance territorial cohesion: "Whenever [a Member of the European Parliament] gathers us, they tell us that we don't write enough projects. Well, we would actually write them, but what should we apply for? A lot of mayors want to write these applications but there's no sense [because they cannot score enough points]" (interview No. 10).

One aspect that the interviews highlight beyond implementation fallacies is the unclear nature of the knowledge that is attached to territorial cohesion components. As signalled in Section 2, a first contributing factor can be attributed to the prominent meta-cultural frame

6) I have borrowed the conceptual distinction between normative and cognitive ideals from CAMPBELL (1988). 
across Eastern Europe that has stigmatised strategic spatial planning as the harbinger of doom for the return of an undesirable "socialist approach" to development (MAIER 2012). In Romania's case it appears that the planning profession has been gradually eroded to the point that "nowadays very few politicians have access to a specialist with whom they can discuss territorial planning" (interview No. 9). As a result, the narrative of regional development is predominantly shaped by policy technicalities. There is indeed an acute lack of actors who could explain what a territorially integrated strategy might look like. When planning matters are discussed, issues tend to be approached "with a certain formalism, perhaps even a form of languor" (interview No. 16). Very practically put, experts "find it very hard to convince people that a project which is not on their turf could in fact benefit the whole region" (interview No. 9).

Second, it appears that debates on policy concepts are confined to the technicalities attached to the instruments that implement them. For instance, governmental-level discussions related to endogenous potentials were signalled as being exclusively focused on finding a common ground between participants which were most interested in identifying financing lines for their priorities (interview No. 15). Such discussions tend to be characterised as being "rather tense, with the whole approach not being very constructive" (interview No. 6). As a result, the policy provisions are overwhelmingly shaped by bureaucratic interpretations of EU norms. Given this, many interviewed local actors have signalled the inextricable pomposity of these concepts, in a context where the needs are much more basic (interview No. 9, interview No. 12). This impacts the applicability of the official policy narrative to contexts where it is applied in - multiple actors have for instance highlighted the unsuitability of the competitiveness goal, not as a false narrative per se but as unrealistic. This points back to the fact that through its excessive orientation towards growth, top-down interpretations of territorial cohesion overlook the myriad of specific conditions that are inherent to regions for which the globalised competitiveness growth model might not be the most beneficial solution (see also LEICK and LANG 2018; Demeterova et al. 2020a).

\section{Conclusions and outlook}

In this paper I set out to offer a bottom-up perspective on the transfer of a territorial cohesion ideal in a South-East European EU Member State. Romania's case is an example of a context that has pursued a growth-pole driven polycentric model of territorial development. The use of polycentricity is a verbatim reflection of the arguments for concentrated growth-driven competitiveness made at an EU level (see Section 2). On the other hand, the "integrated" side of "integrated polycentric development" appears to have been reduced to a normative construct of combining soft and hard investments at a local level, and in some instances at a regional level through LEADER (in places where the management has had the knowledge and drive to push more complex strategies through).

So, to return to my initial question: Which institutional conditions have underpinned the emergence of the current state of affairs? A first observation is that the centralised logic of decision-making has not only remained untouched but has also diversified. 
Policy designers are put into the impossible position of designing programmes and promoting a policy narrative that applies uniformly across the country. The opening of national decision-making processes (as indeed intended by the Lisbon Agenda) is seen to have been implemented in the spirit of fulfilling a formality, rather than in the sense of democratising national decision-making processes. As a result, the understanding of integrated polycentric development (in this case) that prevails appears to be produced in the ivory decision-making towers of governmental departments. This process is so opaque, that a considerable number of interviewed actors have asked themselves whether there actually is a national strategy that guides policy designs, or whether the implemented policies have been designed as punctual reactions to the European Commission's suggestions.

A second observation concerns the term's bottom-up construction. Namely, its bottom-up meanings emerge in the context of an overly bureaucratised policy delivery system and fierce individual competition for resources. Expecting that such a context might be ripe for the reconstruction of the "integrated" arm of "integrated polycentric development" might be overly optimistic. Also, there is a general distrust between the different layers of government involved in policy delivery (see Subsection 5.3).

A second question I asked at the outset was: How is the tension inherent to the notion of integrated polycentric development resolved? The blunt answer is that the struggle between two different logics of territorial organisation is ongoing. On the one hand, the international counselling received by the government points towards a model driven by territorial concentration. On the other hand, national policy designers must act in accordance with a fragile balance of power between local and national political factors (see Subsection 5.1). So far, this struggle has played out episodically. The 2007-2013 MFF was an era of the seven growth poles and 17 development poles, while during the 2014-2020 MFF their number has increased to 42. The logic of centralised growth has nonetheless remained, despite an attempted decentralisation. This is a clear marker that the dimensions of integrated polycentric development that have gained ideational power were those that could serve the goal of bridging the economic gap in a starkly unequal Single Market. The initial idea underpinning polycentric development (i.e., the establishment of global integration zones) appears to live on some thirty years after its inception while other concepts that plead for integration have been less (e.g. urban-rural relations).

The very end of the paper is typically reserved for policy recommendations. I find myself in the unfortunate position to advise policymakers on a matter (disparities in social and economic welfare) that, to paraphrase $\operatorname{MoLLE}(2007$, p. 7) is subject to political and social forbearance. I will therefore tread lightly by suggesting that the time is right to consider the usefulness of concepts that specifically target the very diverse development challenges of peripheralised places and explore what an integrated territorial development approach might mean for such areas from their perspective. As HumER (2018) points out, conceptually bridging the gap between rural/peripheral development (terms which are often more or less voluntarily conflated) and urban development is of a salient importance. This link cannot be established as a blanket solution, even at a conceptual level - the EU is simply too diverse for that (see for instance CopUs 2018). Moreover, 
this discussion must be detached from the seven-year policy cycle created by the MFF to avoid the fragmentation of thinking along the lines of Operational Programmes and the constant recreation of the financing conditions they seem to induce. Another principle is that measures based on the notion of territorial cohesion should target experimental new solutions. Given the immensity of the task of finding common grounds for aspects such as "fair access to services", thought should be given to the feasibility of grasping the issue relationally instead of purely territorially. As FALUDi (2016) argues, the added value of territorial cohesion could, for instance, be that it provides the grounds for new flexible patterns of decision-making for those directly affected by an issue. Of course, the challenge directly related to that will be to design a system that fosters the long-term sustainability of measures which turn out to be successful and impactful.

\section{Acknowledgements}

The research leading to these results was conducted as part of the framework of the project "Socio-economic and Political Responses to Regional Polarisation in Central and Eastern Europe" (RegPol2), coordinated by the Leibniz Institut für Länderkunde (IFL) [Leibniz Institute for Regional Geography], Leipzig, Germany. The project received funding from the People Programme (Marie Curie Actions) of the European Union's Seventh Framework Programme FP7/2007-2013/ (REA grant agreement number 607022).

I would like to thank the anonymous reviewers and the editors for their constructive comments on an earlier version of this paper. I would also like to thank the Leibniz Institute for Regional Geography in Leipzig and the Department of Geography at the BabeșBolyai University in Cluj-Napoca for the support provided in conducting the research upon which this article is based. Last, I extend my thanks to the people who agreed to be interviewed - this paper would have not been possible without their input.

\section{References}

Abrahams G. (2014): What "Is" Territorial Cohesion? What Does It "Do"? Essentialist versus Pragmatic Approaches to Using Concepts. In: European Planning Studies, 22 (10), pp. 2134 2155.

Agenția de Dezvoltare Regională (ADR) Nord-Vest (2014): Planul de dezvoltare al regiunii NordVest 2014-2020 [The North-West region's development plan 2014-2020]. Cluj-Napoca: ADR Nord-Vest [Regional Development Agency North-West].

Avdikos V., Chardas A. (2016): European Union Cohesion Policy post 2014: More (place-based and conditional) Growth-Less Redistribution and Cohesion. In: Territory, Politics, Governance, 4 (1), pp. 97-117.

Bachtler J., McMaster I. (2008): EU Cohesion Policy and the Role of the Regions: Investigating the Influence of Structural Funds in the New Member States. In: Environment and Planning C: Government and Policy, 26 (2), pp. 398-427.

BegG I. (2010): Cohesion or Confusion: A Policy Searching for Objectives. In: Journal of European Integration, 32 (1), pp. 77-96. 
Benedek J., Varvari Ş., Litan C. M. (2019): Urban Growth Pole Policy and Regional Development: Old Wine in New Bottles? In: Lang T., Görmar F. (eds.): Regional and Local Development in Times of Polarisation: Re-thinking Spatial Policies in Europe. Basingstoke: Palgrave Macmillan, pp. 173-195.

Bevir M., Rhodes R. A. W. (2010): The State as Cultural Practice. Oxford: Oxford University Press. Blankespoor B., Burduja S. I., Cojocaru S. L., Ionescu-Heroiu M., Iorga E., Man T.-C., Moldovan S. C., Moreti E., Rus R., Sandu, D. D., van der Weide R. (2013): Romania - Competitive Cities: Reshaping the Economic Geography of Romania: Full report (English). Washington DC: World Bank Group. - http://documents.worldbank.org/curated/en/ 664361468093270286/Full-report (last access: June 26, 2019).

Blažé J., MacešKová M. (2018): Challenges for National Policies in the New Member States. In: Gorzelak G., Bachtler J., SmętKowski M. (eds.): Regional Development in Central and Eastern Europe: Development Processes and Policy Challenges. London: Routledge, pp. 59-70.

Bogner A., Menz W. (2002): Das theoriegenerierende Experteninterview. Erkenntnisinteresse, Wissensformen, Interaktion [The Theory-Generating Expert Interview: Epistemological Interest, Forms of Knowledge, Interaction]. In: Bogner A., Littig B., Menz W. (eds.): Das Experteninterview. Theorie, Methode, Anwendung [The Expert Interview. Theory, Method, Application]. Wiesbaden: Springer Fachmedien, pp. 33-70.

Böhme K., Gløersen E. (2011): Territorial Cohesion Storylines: Understanding a Policy Concept. Heisdorf, Lux.: Spatial Foresight GmbH (= Spatial Foresight Briefing, 2011:1). - https:// www.spatialforesight.eu/files/spatial theme/spatial/publications/Brief-2011-1-111025.pdf (last access: June 30, 2019).

CAmpbell J. L. (1988): Institutional Analysis and the Role of Ideas in Political Economy. In: Theory and Society, 27 (3), pp. 377-409.

Capano G., Howlett M. (2019): Causal Logics and Mechanisms in Policy Design: How and Why Adopting a Mechanistic Perspective Can Improve Policy Design. In: Public Policy and Administration, online publication. - https://doi.org/10.1177/0952076719827068.

Charmaz K. (2006): Constructing Grounded Theory. London: Sage.

Chilla T., Neufeld M. (2015): Cohesion as a Multi-Scalar Challenge: The EU-Wide Perspective. In: Lang T., Henn S., Sgibnev W., Ehrlich K. (eds.): Understanding Geographies of Polarization and Peripheralization. Perspectives from Central and Eastern Europe and Beyond. Basingstoke: Palgrave Macmillan, pp. 199-216.

Churski,P., Perdal R. (2016): Where Do Cohesion Policy Funds Flow and Do They Have Any Impact? The Polish Lesson. In: Barometr Regionalny. Analizy i Prognozy [Regional Barometer. Analyses and Forecasts], 14 (3), pp. 7-24.

Colomb C., Santinha G. (2014): European Union Competition Policy and the European Territorial Cohesion Agenda: An Impossible Reconciliation? State Aid Rules and Public Service Liberalization through the European Spatial Planning Lens. In: European Planning Studies, 22 (3), pp. 459-480.

Commission of the European Communities (1999): European Spatial Development Perspective: Towards Balanced and Sustainable Development of the Territory of the EU. Luxembourg: Office for Official Publications of the European Communities.

Commission of the European Communities (2008): Green Paper on Territorial Cohesion Turning Territorial Diversity into Strength. Brussels: Commission of the European Communities.

Consolidated Version of the Treaty on the Functioning of the European Union (2012). In: Official Journal of the European Union, 55 (C 326/1), pp. 46-390. 
Copus A. K. (2018): The New Rural Economy and Macro-scale Patterns. In: Copus A. K., DE LimA P. (eds.): Territorial Cohesion in Rural Europe: The Relational Turn in Rural Development. Abingdon: Routledge, pp. 11-34.

Csuka G. (2018): The Competitiveness of Central and Eastern European Countries. An Analysis of the Legal Environment. In: Gorzelak G., Bachtler J., SmętKowski M. (eds.): Regional Development in Central and Eastern Europe: Development Processes and Policy Challenges. London: Routledge, pp. 59-70.

DabinetT G., Richardson T. (2005): The Europeanization of Spatial Strategy: Shaping Regions and Spatial Justice through Governmental Ideas. In: International Planning Studies, 10 (34), pp. 201-218.

DĄBRowski M. (2014): Towards Place-based Regional and Local Development Strategies in Central and Eastern Europe? EU Cohesion Policy and Strategic Planning Capacity at the Subnational Level. In: Local Economy, 29 (4-5), pp. 378-393.

Dao H., Plagnat Cantoreggi P., Rousseaux V. (2017): Operationalizing a Contested Concept: Indicators of Territorial Cohesion. In: European Planning Studies, 25 (4), pp. 638-660.

Davoudi S. (2005): Understanding Territorial Cohesion. In: Planning, Practice \& Research, 20 (4), pp. 433-441.

De Boe P., Hanquet T. (2004): Goals and Concepts. In: Bundesamt für Bauwesen und Raumordnung [Federal Office for Building and Regional Planning] (ed.): ESPON 3.1 Integrated Tools for European Spatial Development. Final Report Part C: New Tools and Instruments for European Spatial Analysis. Bonn: Bundesamt für Bauwesen und Raumordnung.

Demeterova B., Fischer T., Schmude J. (2020a). The Right to Not Catch Up - Transitioning European Territorial Cohesion Towards Spatial Justice for Sustainability. In: Sustainability, 12 (11), online publication. - https://doi.org/10.1080/09654313. 2020.1716692.

Demeterova B., Goodwin-Hawkins B., Fischer T. (2020b): Conceptualisations of Territorial Cohesion in Central European Border Regions. In: European Planning Studies, 28 (12), pp. 2287-2306.

Dranca D. (2013): Cluj-Napoca Metropolitan Zone: Between a Growth Pole and a Deprived Area. In: Transylvanian Review of Administrative Sciences, 9 (40), pp. 49-70.

Ernste H. (2012): Framing Cultures of Spatial Planning. In: Planning Practice and Research, 27 (1), pp. 87-101.

European Commission (2017): Seventh Report on Economic, Social and Territorial Cohesion. Luxembourg: Publications Office of the European Union.

European Spatial Planning Observation Network (2007): ESPON Project 3.2 - Scenarios on the Territorial Future of Europe. Luxembourg: Ministry of Interior and Spatial Development in Luxembourg. - http://www.espon.eu/main/Menu_Projects/Menu_ESPON2006Projects/ Menu_CoordinatingCrossThematicProjects/scenarios.html (last access: August 31, 2020).

European Spatial Planning Observation Network (2011): INTERCO. Indicators of territorial cohesion. Scientific Platform and Tools Project 2013/3/2 Interim Report, Version 31/03/2011. - https:// www.espon.eu/sites/default/files/attachments/INTERCO_Interim_Report.pdf (last access: August 31, 2020).

European Spatial Planning Observation Network (2013): INTERCO. Indicators of Territorial Cohesion. Scientific Platform and Tools Project 2013/3/2. Final Report. Luxembourg: ESPON Coordination Unit.

Faludi A. (2005): Polycentric Territorial Cohesion Policy. In: The Town Planning Review, 76 (1), pp. 107-118. 
Faludi A. (2010): The Process Architecture of EU Territorial Cohesion Policy. In: European Journal of Spatial Development, 39, online publication. - https://archive.nordregio.se/Global/ EJSD/Refereed\%20articles/refereed39.pdf.

Faludi A. (2016): EU Territorial Cohesion, a Contradiction in Terms. In: Planning Theory \& Practice, 17 (2), pp. 302-313.

Faludi A., Waterhout B. (2002): The Making of the European Spatial Development Perspective. No Masterplan. Abingdon: Routledge.

FARAGó L., VARró K. (2016): Shifts in EU Cohesion Policy and Processes of Peripheralisation: A View from Central Eastern Europe. In: European Spatial Research and Policy, 23 (1), pp. 5-19.

Glaser B., Strauss A. (1967): The Discovery of Grounded Theory. London: Weidenfield \& Nicolson.

Glynos J., Howarth D. (2008): Structure, Agency and Power in Political Analysis: Beyond Contextualised Self-interpretations. In: Political Studies Review, 6 (2), pp. 155-169.

Griggs S., Norval A. J., WagenaAr H. (2014): Practices of Freedom: Decentered Governance, Conflict and Democratic Participation. New York: Cambridge University Press.

Gruber E., Rauhut D., Humer A. (2019): Territorial Cohesion Under Pressure? Welfare Policy and Planning Responses in Austrian and Swedish Peripheries. In: Papers in Regional Science, 98 (1), pp. 115-132.

Gualini E. (2008): Territorial Cohesion as a Category of Agency: The Missing Dimension in the EU Spatial Policy Debate. In: European Journal of Spatial Development, 28, online publication. - http://www.nordregio.se/EJSD/refereed28.pdf.

Hadjimichalis C., Hudson R. (2014): Contemporary Crisis Across Europe and the Crisis of Regional Development Theories. In: Regional Studies, 48 (1), pp. 208-218.

HANELL T. (2018): Regional Quality of Life in the EU: Comprehending the European Space Beyond GDP through the Capability Approach. Doctoral Thesis, Aalto University, Espoo / Helsinki.

Herrschel T. (2011): Regional Development, Peripheralisation and Marginalisation - and the Role of Governance. In: Herrschel T., Tallberg P. (eds): The Role of Regions? Networks, Scale, Territory. Kristianstad: Kristianstads Boktryckeri, pp. 85-102.

Hotărârea Guvernului nr. 998/2008 pentru desemnarea polilor de creștere și a polilor de dezvoltare urbană în care se realizează cu prioritate investiții din programele cu finanțare comunitară și națională [Government Decision No. 998/2008 for designating the growth poles and the urban development poles for prioritising investments funded by EU and national programmes] (2008). In: Monitorul Oficial al României nr. 641 din 8 septembrie 2008 [Official Gazette of Romania no. 641 of September 8, 2008].

Humer A. (2018): Linking Polycentricity Concepts to Periphery: Implications for an Integrative Austrian Strategic Spatial Planning Practice. In: European Planning Studies, 26 (4), pp. 635-652.

Jones R., Moisio,S., Weckroth M., Woods M., Luukkonen J., Meyer F., Miggelbrink J. (2019): Re-conceptualising Territorial Cohesion Through the Prism of Spatial Justice: Critical Perspectives on Academic and Policy Discourses. In: Lang T., Görmar F. (eds.): Regional and Local Development in Times of Polarisation: Re-thinking Spatial Policies in Europe. Basingstoke: Palgrave Macmillan, pp. 97-119.

Legea nr. 350/06.07.2001 privind amenajarea teritoriului şi urbanismul [Law No. 350/06.07.2001 concerning territorial planning and urbanism]. In: Monitorul Oficial al României nr. 373 din 10 iulie 2001 [Official Gazette of Romania no. 373 of July 10, 2001].

Leick B., Lang T. (2018): Re-thinking Non-core Regions: Planning Strategies and Practices Beyond Growth. In: European Planning Studies, 26 (2), pp. 213-228.

Luukkonen J. (2010): Territorial Cohesion Policy in the Light of Peripherality. In: Town Planning Review, 81 (4), pp. 445466. 
MAIER K. (2012): Europeanization and Changing Planning in East-Central Europe: An Easterner's view. In: Planning Practice and Research, 27 (1), pp. 137-154.

Maloutas T. (2018): Travelling Concepts and Universal Particularisms: A Reappraisal of Gentrification's Global Reach. In: European Urban and Regional Studies, 25 (3), pp. 250-265.

MalÝ J., MulíčECK O. (2016): European Territorial Cohesion Policies: Parallels to Socialist Central Planning? In: Moravian Geographical Reports, 24 (1), pp. 14-26.

McAnulla S. (2006): Challenging the New Interpretivist Approach: Towards a Critical Realist Alternative. In: British Politics, 1 (1), pp. 113-138.

Medeiros E. (2016): Territorial Cohesion: An EU Concept. In: European Journal of Spatial Development, 60, online publication. - http://www.nordregio.se/Global/EJSD/Refereedarticles/ refereed60.pdf.

Medve-BÁlint G. (2018): The Cohesion Policy on the EU's Eastern and Southern Periphery: Misallocated Funds? In: Studies in Comparative International Development, 53 (2), pp. 218-238.

Mendez C. (2011): The Lisbonization of EU Cohesion Policy: A Successful Case of Experimentalist Governance? In: European Planning Studies, 19 (3), pp. 519-537.

Ministry of Economy and Finance (2007): National Strategic Reference Framework for Romania [NSRF] 2007-2013. - http://old.fonduri-ue.ro/res/filepicker_users/cd25a597fd-62/Doc_ prog/CSNR/1_CSNR_2007-2013_(eng.).pdf(last access: June 26, 2019).

Molle W. (2007): European Cohesion Policy. London: Routledge.

Muller H. B. M. (2013): The Place where Streams Seek Ground. Towards a New Territorial Governmentality: The Meaning and Usage of the Concept of Territorial Cohesion in the European Union. Doctoral Thesis, University of Amsterdam.

Nemes G., High C., Augustyn A. (2018): Beyond the New Rural Paradigm: Project State and Collective Reflexive Agency. In: Copus A. K., DE Lima P. (eds.): Territorial Cohesion in Rural Europe: The Relational Turn in Rural Development. Abingdon: Routledge, pp. 212-235.

Othengrafen F., Cornett A. P. (2013): A Critical Assessment of the Added Value of Territorial Cohesion. In: European Journal of Spatial Development, 53, online publication. - http:// www.nordregio.se/Global/EJSD/Refereedarticles/refereed53.pdf.

Partridge M. D., Rickman D. S., Olfert M. R., TAN Y. (2015): When Spatial Equilibrium Fails: Is Place-based Policy Second Best? In: Regional Studies, 49 (8), pp. 1303-1325.

PRus R. (1996): Symbolic Interaction and Ethnographic Research. Albany, NY: State University of New York Press.

RAdEJ B., Golobič M. (2018): Integration Problem. In: Research in Social Change, 10 (2), pp. 32-67.

Rauhut D. (2017): Polycentricity - One Concept or Many? In: European Planning Studies, 25 (2), pp. 332-348.

Rauhut D., Humer A. (2020): EU Cohesion Policy and Spatial Economic Growth: Trajectories in Economic Thought. In: European Planning Studies, 28 (11), pp. 2116-2133.

Research Group PoSCoPP (2015): Understanding New Geographies of Central and Eastern Europe. In: Lang T., Henn S., Sgibnev W., Ehrlich K. (eds.): Understanding Geographies of Polarization and Peripheralization. Perspectives from Central and Eastern Europe and Beyond. Basingstoke: Palgrave Macmillan, pp. 1-21.

Rodríguez-Pose A. (2017): The Revenge of the Places that Don't Matter (and What to Do About It). In: Cambridge Journal of Regions, Economy and Society, 11 (1), pp. 189-209.

Servillo L. (2010): Territorial Cohesion Discourses: Hegemonic Strategic Concepts in European Spatial Planning. In: Planning Theory \& Practice, 11 (3), pp. 397-416.

Shaw D., Sykes O. (2004): The Concept of Polycentricity in European Spatial Planning: Reflections on its Interpretation and Application in the Practice of Spatial Planning. In: International Planning Studies, 9 (4), pp. 283-306. 
Smętкowski M. (2013): Regional Disparities in Central and Eastern European Countries: Trends, Drivers and Prospects. In: Europe-Asia Studies, 65 (8), pp. 1529-1554.

Sмiтн A., TimáR J. (2010): Uneven Transformations: Space, Economy and Society 20 Years After the Collapse of State Socialism. In: European Urban and Regional Studies, 17 (2), pp. 115-125.

Sмiтн M. J. (2008): Re-centring British Government: Beliefs, Traditions and Dilemmas in Political Science. In: Political Studies Review, 6 (2), pp. 143-154.

StĂNescu I. (2015). Procesul de regionalizare-descentralizare: o analiza critică [The Regionalisation-Descentralisation Process: A Critical Analysis]. In: STĂNesCu I., ZAmFIR,C. (eds.): România la răscruce. Opțiuni pentru viitor [Romania at a Crossroad. Options for the Future]. Bucharest: Pro Universitaria, pp. 44-80.

van Meeteren M., Poorthuis A., Derudder B., Witlox F. (2016): Pacifying Babel's Tower: A Scientometric Analysis of Polycentricity in Urban Research. In: Urban Studies, 53 (6), pp. $1278-1298$.

VANolo A. (2010): European Spatial Planning Between Competitiveness and Territorial Cohesion: Shadows of Neo-liberalism. In: European Planning Studies, 18 (8), pp. 1301-1315.

WagenaAr H. (2012): Dwellers on the Threshold of Practice: The Interpretivism of Bevir and Rhodes. In: Critical Policy Studies, 6 (1), pp. 85-99.

Waterhout B. (2008): The Institutionalisation of European Spatial Planning. Amsterdam: IOS Press. 